\title{
Report of the EuroMAB Conference 2017, Building a sustainable future together, Dordogne Basin Biosphere Reserve, Sarlat-la-Canéda, (France), 4-7 April 2017
}

\author{
Günter Köck, Marja Spierenburg, Petr Čupa, Raphael Mathevet \& Vanja Debevec
}

Abstract

The EuroMAB Network includes all European and North-American member states which participate in UNESCO's Man and the Biosphere (MAB) Programme and its World Network of Biosphere Reserves (WNBR). EuroMAB is the largest and oldest of the nine regional and inter-regional MAB Networks. It is made up of 36 countries, including Canada and the USA, and includes 302 biosphere reserves (BRs). Bringing together almost half of the total WNBR sites, the EuroMAB Network is a platform for sharing knowledge, know-how and experience of sustainable development, as well as a collective tool for supporting sustainable development practices among BR coordinators, scientists and MAB National Committees. Since the first meeting in 1986 in České Budêjovice, Czech Republic, the MAB National Committees and BR coordinators of EuroMAB have met nearly every two years. EuroMAB conferences have been held in Minsk, Belarus (1997), Cambridge, UK (2000), Rome, Italy (2002), Hernstein, Austria (2005), Antalya, Turkey (2007), Stará Lesná, Slovakia (2009), Lundsbrunn, Sweden (2011), Brockeville, Canada (2013), and Haapsalu, Estonia (2015). EuroMAB meetings are dedicated to bringing together BR managers, coordinators, scientists and representatives of UNESCO's MAB Secretariat, MAB National Committees and partner institutions/associations.

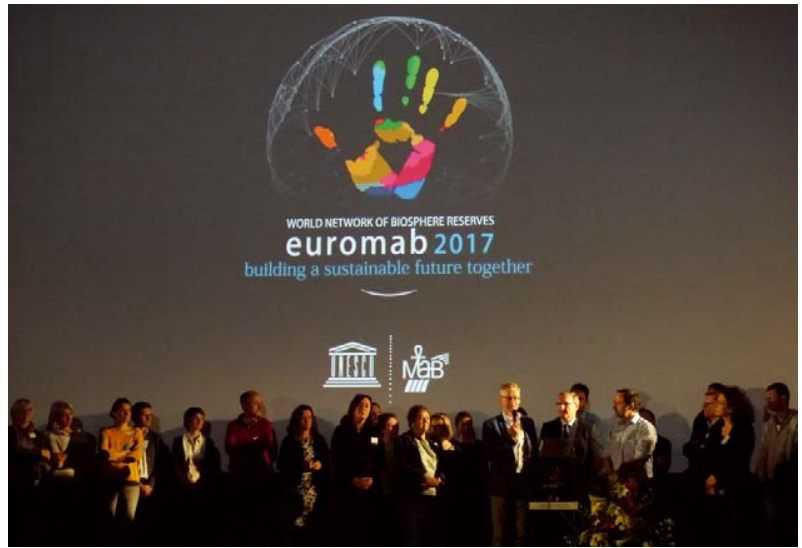

EuroMAB 2017 gathered more than 220 delegates from 41 countries at Sarlat-la-Canéda, France, inside the beautiful Dordogne Basin BR, the largest BR in France and one of the rare BRs within the WNBR that incorporate a whole catchment basin.

The aim of the meeting was in keeping with the $4^{\text {th }}$ World Congress of Biosphere Reserves held in Lima (Peru) in March 2016, which led to the adoption of the Lima Action Plan (LAP) 2016-2025. The LAP is a new ten-year action plan for the MAB Programme, with nearly 60 concrete actions for strengthening the WNBR and its individual BRs over the next ten years, and aims to promote synergies between BRs and the Sustainable Development Goals (SDGs) of the United Nations' 2030 Agenda for Sustainable Development, adopted in Paris in 2015.

Under the motto Building a Sustainable Future Together, conference participants discussed how BRs can contribute to SDGs, to multilateral environmental agreements (MEAs), and to the Paris Agreement on Climate Change 2015. In addition, participants worked on identifying which new types of partnerships are necessary for an ecological transition, how to set them up and how to maintain and promote them in the long run.

EuroMAB 2017 started with a public conference attracting more than 340 representatives of the BRs of the EuroMAB network, sustainable development stakeholders, experts, researchers, representatives of National Committees, UNESCO, the French government and French public organizations. In his opening address Christophe Aubel (Director of the French Agency for Biodiversity), highlighted the challenges of biodiversity conservation and its inalienability in securing a sustainable future.

To facilitate collective approaches and collaborative projects, 16 participative workshops were organized to address more than two-thirds of the 17 SDGs (Table 1).

Many participants used the poster exhibition and side events to present their BRs and scientific work and other projects carried out in their BRs (e.g. L. Gohan, Israel Institute of Technology: How does the planning process impact Biosphere Reserve implementation?; G. Köck, Austrian Academy of Sciences: MAB Research in Austria; A. Bell, UK, and G. Clarke, Canada: International Centre for Sustainable Rural Communities). Philippe Pypaert (UNESCO Regional Bureau for Science and Culture in Europe, Venice) announced the 2017 MAB Youth Forum which will be held from 18-22 September 2017 in the Po Delta BR in Rosolina Mare (Italy). The Forum targets young adults, aged between 18 and 35 , who live or work in BRs, or who study or conduct research in the areas. It will offer a unique opportunity for participants to meet, debate and share their vision and commitment to sustainable development.

The EuroMAB meeting also became the scene of an unforeseen example of local participation when groups of supporters as well as opponents of a new bypass road construction for the village of Beynac used it to present, in peaceful actions, their arguments and concerns to the conference participants. 
Table 1 - Workshopsat the EuroMAB Conference 2017.

\begin{tabular}{|c|c|c|}
\hline Workshop title & Chairs and presenters & SDGs addressed' \\
\hline $\begin{array}{l}\text { Communication and branding - developing the MAB } \\
\text { Global Communication Strategy }\end{array}$ & $\begin{array}{l}\text { Eve Ferguson (Canada), Jeff Melnyk (UK), Laurie Bennett } \\
\text { (UK) }\end{array}$ & 8,12 \\
\hline Partnerships between BRs and universities & $\begin{array}{l}\text { Maureen Reed (Canada), Catherien Cibien (France), Alice } \\
\text { Roth (France), Heinrich Mayer (Austria) }\end{array}$ & 4,17 \\
\hline Support desk & $\begin{array}{l}\text { Vanja Debevec (Slovenia), Petr Čupa (Czech Republic), } \\
\text { Raphaël Mathevet (France), Marja Spierenburg (Nether- } \\
\text { lands) }\end{array}$ & 17 \\
\hline Governance & Mireille Jardin (France), Olaf Ostermann (Germany) & 17 \\
\hline $\begin{array}{l}\text { Networking river and watershed BRs - building a continen- } \\
\text { tal freshwater ecosystems } M A B \text { network }\end{array}$ & Guy Pustelnik (France), Eva Jelínková (Czech Republic) & 6,17 \\
\hline BRs and scientific partnerships & $\begin{array}{l}\text { Anna Echassoux (France), Martin Price (UK), Maureen } \\
\text { Reed (Canada), Phyllis Green (USA), Andrew Bell (UK), } \\
\text { Pamela Shaw (USA) }\end{array}$ & 17 \\
\hline $\begin{array}{l}\text { Urban areas - an opportunity for BRs to work for (and } \\
\text { with?) people where they live }\end{array}$ & $\begin{array}{l}\text { Leslie Moore (Ireland), Rich Howorth (UK), Marco Valle } \\
\text { (Italy), Niamh Ni Cholmain (Ireland) }\end{array}$ & 11,13 \\
\hline EuroMAB partnerships around the Mediterranean & Ken Reyna (France), Gordana Beltram (Slovenia) & 17 \\
\hline Transboundary BRs & Mireille Jardin (France), Álvaro de Torres Suárez (Spain) & 17 \\
\hline $\begin{array}{l}\text { Nord MAB - Training workshops in communication for BRs } \\
\text { within the NordMAB network }\end{array}$ & $\begin{array}{l}\text { Kari Evensen Natland (Norway), Johanna MacTaggart } \\
\text { (Sweden), Jeff Melnyk (UK) }\end{array}$ & 6,17 \\
\hline Ecosystem services, stakeholders and territories & Cécile Barnaud (France), Juana Barber Rosado (Spain) & $1,3,6,10,12,15$ \\
\hline Connection with nature, human well-being & Anne-Caroline Prévot (France), Christian Diry (Austria) & 3,15 \\
\hline Indigenous people & Larry McDermott (Canada), Rebecca Hurwitz (Canada) & $\begin{array}{r}10,11,12,13, \\
14,15,17\end{array}$ \\
\hline BRs and climate change & $\begin{array}{l}\text { Jean-Philippe Messier (Canada), Barbara Engels (Ger- } \\
\text { many), Andrew Bell (UK) }\end{array}$ & 7,13 \\
\hline Partnerships between BRs and the economic sector & $\begin{array}{l}\text { Johanna MacTaggart (Sweden), Carlo Ossola (Switzer- } \\
\text { land), Catherine Cibien (France), Annette Schmidt (Swit- } \\
\text { zerland), Colin Campbell (UK), Laure Bou (France), Juliette } \\
\text { Cerceau (France) }\end{array}$ & $8,12,17$ \\
\hline International Centre for Sustainable Rural Communities & Andy Bell (UK), Gary Clarke (Canada) & $11,12,15$ \\
\hline
\end{tabular}

${ }^{1}$ Numbers according to the official UN numberings of SDGs - bttp:// wnw.un.org/sustainabledevelopment/sustainable-development-goals

A traditional element of all EuroMAB meetings from the beginning, the popular so-called ethnic evening provided the opportunity for the BRs to bring, present and share their culinary, musical or festive specialties. Study trips within Dordogne Basin BR as well as pre / post-conference tours to four other French BRs completed the conference.

On the last day of the conference, a group of workshop rapporteurs presented a first summary of the main issues addressed in the workshops. The EuroMAB 2017 reflected the readiness of BRs from Europe, Canada and USA to contribute actions and efforts to promote the SDGs and implement the LAP. There was a clear shift in the MAB programme presentations, with an emphasis on the growing importance and momentum of sustainable development and participatory site management. Research as one of the three key functions of the programme - also received a lot of attention, and in a more inclusive way than before: there was a strong focus on inter- and transdisciplinary research, firmly integrating social sciences as well as local and indigenous knowledge, and on the practical application of research outcomes.

Proposals for partnerships between BRs related to effective management of BRs and included local communities, business partners and international organizations. Governance was addressed in many discussions and a wide range of successful models were presented as well. More detailed research on that topic can be expected in the future.

Discussion also covered several projects with distinguished results in education, public awareness and scientific research. It could be demonstrated that outcomes of these activities have helped to strengthen efforts in addressing the issues related to ecosystem services and to climate change. A Memorandum of Understanding for cooperation between BRs focusing on continental freshwater ecosystems within the MAB network was prepared, as well as cooperation between sites containing cities.

There was strong emphasis on establishing effective communication between BRs and participants of workshops proposed ways to ensure continuity in the exchange of ideas, best practices and progress through joint actions. The EuroMAB network will share positive outcomes of recent work with other networks. Communication tools that were developed and tested in BRs will be shared within the Asian and AfriMAB networks.

The support desk workshop was organized by the members of the International Advisory Committee (IAC) for BRs. Participants addressed several issues related to nomination and periodic review processes. A revision of the forms was proposed as well as the need for Operational Guidelines. The assurance of proper forms of support that will be available in the future - in cooperation with members of IAC - and 
the proposed mentoring programme for BRs were considered very useful.

To conclude, the EuroMAB 2017 conference was another excellent networking opportunity for European and North-American BRs, MAB National Committees and scientists. Furthermore, it was a perfect venue for sharing experiences, views and ideas, as well as a great occasion to promote biodiversity conservation and sustainable development around the world. Special thanks are due to the Organizing Committee: Catherine Cibien (Secretary General, MAB France), Didier Babin (Chair, MAB France), Meriem Bouamrane (UNESCO-MAB Secretariat), Germinal Peiro (Chair (Chair Dordogne Basin BR, EPIDOR), Guy Pustelnik (Coordinator Dordogne Basin BR, EPIDOR) and his team, plus a large group of local volunteers. The EuroMAB community is looking forward to the next EuroMAB conference, hosted in 2019 by the Republic of Ireland in Dublin Bay BR.

More information about the EuroMAB network as well as the official Conference Report can be found at http://www.unesco.org/new/en/naturalsciences/environment/ecological-sciences/man-andbiosphere-programme/networks/euromab/

Detailed information about the 2017 MAB Youth Forum and the application form are available at https://www.MYForum2017.com/

\section{Authors}

\section{Günter Köck}

is Secretary General of the Austrian MAB National Committee, former Vice-Chair of the UNESCO MAB Programme, and the Austrian delegate to the European Alliance of Global Change Research Committees, member of the Scientific Board of Hohe Tauern National Park, as well as one of the Austrian delegates to the International Scientific Committee for Alpine Research. In 2009 he became co-editor of eco.mont. In addition, he is Research Associate at the Institute for Interdisciplinary Mountain Research (IGF) in Innsbruck, working on the effects of climate change in Alpine and Arctic regions.

\section{Marja Spierenburg}

is Professor of Development Studies at Radboud University in Nijmegen (Netherlands) and is affiliated to Stellenbosch University in South Africa. Her research focuses on the role of the private sector in nature conservation and land reforms in Southern Af- rica. She is (co-)vice-chair of the Scientific Committee of the Programme on Ecosystem Change and Society, one of Future Earth's core projects. She is also a member of the International Advisory Committee for Biosphere Reserves, and she chairs the Scientific Advisory Board of the African Studies Centre Leiden.

Petr Čupa

is a Deputy Director of the Lower Morava Biosphere Reserve (LMBR) in the Czech Republic. His work focuses on conservation of natural and cultural heritage with a participatory approach of stakeholders. His work consists of international cooperation between BRs and Mendel University of Brno. He is also a senior member of the International Advisory Committee for Biosphere Reserves in Paris.

\section{Raphaël Mathevet}

is an ecologist and geographer $(\mathrm{PhD})$ at the CNRS CEFE in Montpellier (France). He works on the conservation of biodiversity, protected areas and conservation planning tools, and adaptive co-management. He applies participatory simulation tools in interdisciplinary approaches to resolve conflicts, especially in the context of Mediterranean wetlands and natural resources management. He is a member of several scientific committees at local, regional and national levels. He is the former Vice-President of the French MAB National Committee and a member of the International Advisory Committee for Biosphere Reserves of the UNESCO MAB Programme, and of the International Scientific Committee of the IHOPE Programme.

\section{Vanja Debevec}

is a biologist (MSc) and Head of the Department for Research and Development at the Public Service Agency Škocjan Caves Park, Slovenia. Her work focuses on conservation of biodiversity, education, participatory approaches in protected areas and on the articulation of multiple designations of World Heritage, $\mathrm{MAB}$ and Ramsar. She is a coordinator of the International Schools Network and the Network of Universities of the Karst BR. She is a member of the World Commission on Protected Areas, Senior Responsible Advisor in the International Commission for Speleotherapy at the International Union for Speleology. She also serves as a member of the International Advisory Committee for Biosphere Reserves of the UNESCO MAB Programme. 